\title{
Aksi Bersih Sampah Di Pantai Kejawanan Cirebon dalam Membangun Masyarakat Sadar Sampah
}

\author{
Iing Mustain \\ Akademi Maritim Suaka Bahari Cirebon \\ E-mail: iing.mustain@akmicirebon.ac.id; HP. 081222839838
}

\begin{abstract}
ABSTRAK
Keadaan pantai khususnya di wilayah Cirebon yaitu dari hasil observasi awal yang dilakukan di pantai kejawanan Kota Cirebon ditemukan masih banyak sampah dan kondisi kotor tidak dikelola dengan baik. Tujuan kegiatan bersih sampah untuk memberikan kesadaran bagi pengunjung dan pedagang di kejawanan. Kegiatan Pengabdian Kepada Masyarakat ini dilaksanakan menggunakan metode kegiatan aksi nyata yaitu pelaksanaan aksi bersih sampah pantai kejawanan oleh tim pengabdi diikuti secara aktif oleh seluruh anggota masyarakat yang menjadi khalayak sasaran dan pembinaan bagi masyarakat meliputi penjelasan tentang pengelolaan sampah dan lingkungan hidup, pembentukan kelompok masyarakat sadar lingkungan. Jumlah khalayak sasaran sebanyak 20 masyarakaat di pantai Kejawanan termasuk pedagang di pantai Kejawanan. Seluruh peserta yang terlibat aksi bersih sampah sebanyak 350 orang dengan jumlah catar mencapai 285 orang dan 30 masyarakat dan sisanya dari dosen dan tim pengabdian kepada masyarakat. Kegiatan pembinaan dilakukan dengan partisipasi petugas KPPN pantai Kejawanan terhadap para pedagang dalam pengelolaan pantai kejawanan.
\end{abstract}

Kata Kunci: Pantai, Kotor, Sampah, Tata Kelola Sampah.

\begin{abstract}
The beach condition especially in the Cirebon area which is from the initial observations carried out on the shore of the Cirebon city found that there is still a lot of rubbishes and dirties was not managed well. The purpose of this cleaning act in Kejawanan beach is given awareness of the visitors and mongers. The Community Service activity was carried out using the method of real action activities, namely the implementation of clean actions of the beach garbage by the service team actively participated by all community members who became the target audience and guidance for the community including an explanation of waste management and the environment, the formation of environmentally conscious community groups. The number of target audiences is 20 people at the beach of the Vocational School, including traders on the beach of the Vocational School. All participants involved 350 clean-up actions with the number of cataracts reaching 285 people and 30 communities and the rest from lecturers and community service teams. Coaching activities are carried out with the participation of the beach $K P P N$ Officers against mongers in the management of the beach management.
\end{abstract}

Keyword: Beach, dirty, rubish, waste management. 


\section{PENDAHULUAN}

Kelangsungan hidup masyarakat di pantai dan pulau-pulau kecil di Indonesia perlu ditingkatkan kesadaran akan pentingnya pengelolaan lingkungan hidup yang terpadu dan berkesinambungan untuk kehidupan masa yang akan datang. Masyarakat yang hidup di pulau-pulau kecil memiliki ketergantungan terhadap kondisi pantai dan laut sehingga harus disinkronisasikan dengan peningkatan kesadaran masyarakat. Namun, penduduk pantai yang umumnya padat penduduk dan pendidikan yang rendah menjadi kendala bagi peningkatan dan keterampilan masyarakat. Sebagai konsekwensinya kesadaran masyarakat dan pemahaman pengelolaan lingkungan menjadi permasalahan yang sudah lama dan perlu dicarikan solusinya.

Kehidupan masyarakat di pantai dan pulau-pulau kecil dengan berbagai karakter sosial budaya yang spesifik menjadi keunggulan masyarakat pesisir yang perlu dipertahankan dan dikembangkan di masa yang akan datang. Karakteristik budaya yang kental di pesisir terkadang tidak diimbangi dengan kesadaran terhadap pengelolaan lingkungan di masyarakat. UU 27/2007 tentang Pengelolaan Pesisir dan Pulau-Pulau Kecil mendefinisikan pulau kecil adalah pulau dengan luas lebih kecil atau sama dengan $2.000 \mathrm{Km}^{2}$ (dua ribu kilometer persegi) beserta kesatuan ekosistemnya. Dari definisi tersebut, pulau kecil memiliki dua komponen utama, yaitu ruang daratan yang terbatas dan kesatuan ekosistem. Sedangkan, kesatuan ekosistem yang dimaksud dapat diterjemahkan sebagai kesatuan ekosistem yang ada di daratan pulau dan ekosistem lautnya.

Bila ketentuan tersebut diselaraskan dengan UU 23/1997 tentang Pengelolaan Lingkungan Hidup, dalam konteks pantai dan pulau-pulau kecil, pengelolaan lingkungan hidup dapat diartikan sebagai upaya terpadu untuk melestarikan fungsi lingkungan hidup (daya dukung dan daya tampung) pulau-pulau kecil yang meliputi kebijaksanaan, penataan, pemanfaatan, pengembangan, pemelihataan, pemulihan, pengawasan, dan pengendalian lingkungan hidup. Daya dukung adalah kemampuan lingkungan hidup untuk mendukung perikehidupan manusia dan makhluk hidup lainnya. Daya tampung lingkungan hidup adalah kemampuan lingkungan hidup untuk menyerap zat, energi, dan/atau komponen lain yang masuk atau dimasukkan ke dalamnya.

Pelestarian daya dukung lingkungan hidup adalah rangkaian upaya untuk melindungi kemampuan lingkungan hidup terhadap tekanan perubahan dan/atau dampak negatif yang ditimbulkan oleh suatu kegiatan, agar tetap mampu mendukung perikehidupan manusia dan makhluk hidup lain. Pelestarian daya tampung adalah rangkaian upaya untuk melindungi kemampuan lingkungan hidup untuk meyerap zat, energi, dan/atau koponen lain yang dibuang ke dalamnya.

Masyarakat yang tinggal di pulau-pulau kecil di Indonesia masih belum dilengkapi tata kelola terhadap lingkungan pantai yang baik. Hal ini banyak dijumpai pantai-pantai terlihat sangat kotor dan tidak sehat. Ditambah lagi, paradigma masyarakat pesisir yang menganut bahwa sampah akan hilang dengan sendirinya ketika di buang ke laut. Padahal, sampah yang dibuang ke laut akan merusak ekosistem laut dan pantai. 
Keadaan pantai khususnya di wilayah Cirebon, berdasarkan hasil observasi awal yang dilakukan di pantai kejawanan Kota Cirebon ditemukan masih banyak sampai dan lingkungan kotor tidak dikelola dengan baik khususnya masalah sampah. Belum lagi, masalah tata kelola tempat penampungan sampah skala besar di sekitar pantai belum ada sehingga tidak tertata rapih disebabkan banyak tempat-tempat penampungan sampah kecil yang berserakan.

Oleh karena itu, diperlukan upaya untuk membenahi pengelolaan lingkungan hidup dan meningkatkan kesadaran masyarakat di pantai kejawanan Cirebon melalui upaya bersih-bersih sampah dan pembuatan penampungan sampah akhir khusus yang disebut dengan bank sampah. Dari uraian di atas, maka secara garis besar masalah sampah di pantai kejawanan cirebon menjadi 3 masalah yaitu:

1. Kurangnya kesadaran masyarakat dalam membuang sampah di pantai kejawanan.

2. Kurang aktif dan partisipatisnya masyarakat yang tinggal di pantai untuk membersihkan sampah secara rutin.

3. Perlunya pembinaan yang berkelanjutan bagi masyarakat untuk menumbuhkan kesadaran membuang sampah pada tempatnya

Tujuan dari kegiatan pengabdian ini adalah:

1. Menumbuhkan dan meningkatkan kesadaran masyarakat dalam membuang sampah pada tempatnya tidak sembarang di pantai kejawanan.

2. Meningkatkan aktif dan partisipatis masyarakat yang tinggal di pantai untuk membersihkan sampah secara rutin.

\section{BAHAN DAN METODOLOGI}

Pelaksanaan kegiatan pengabdian dilaksanakan mulai dari tanggal 27 September sampai dengan 27 Oktober 2018 bertempat di pantai Kejawanan. Pantai Kejawanan merupakan pantai wilayah pesisir Kota Cirebon yang menjadi wilayah targetan pengabdian AKMI Suaka Bahari dikarenakan wilayah pantai yang dekat dengan kampus AKMI Cirebon. Pengabdian Kepada Masyarakat ini dilaksanakan menggunakan metode partisipatif (Chamber, 1996) meliputi:

1. Tinjauan pustaka

Mencari landasan teori dari pustaka baik media cetak maupun elektronik. Bekerjasama dengan petugas KPPN Kejawanan memberikan penjelasan tentang pantai kejawanan.

2. Aksi bersih sampah

Tim pengabdi melakukan aksi bersih sampah beserta kelompok masyarakat, dosen, dan Taruna AKMI Suaka Bahari Cirebon.

3. Pelaksanaan Pembimbingan

Tim pengabdi memberikan bimbingan kepada kelompok masyarakat pada khalayak sasaran yang ditargetkan sebanyak 30 kepala keluarga. 


\section{HASIL DAN PEMBAHASAN}

Obyek Wisata Pantai Kejawanan di Pegambiran Cirebon Jawa Barat adalah salah satu tempat wisata yang berada di desa Pegambiran Kecamatan Lemahwungkuk kabupaten Cirebon Provinsi Jawa Barat. Obyek Wisata Pantai Kejawanan di Pegambiran Cirebon Jawa Barat adalah tempat wisata yang ramai dengan wisatawan pada hari biasa maupun hari liburan. Tempat ini sangat indah dan bisa memberikan sensasi yang berbeda dengan aktivitas kita sehari hari. Pantai Kejawanan Cirebon merupakan tempat wisata pantai, tempat pengelolaan ikan (TPI Kejawanan) dan Wisata Terapi.

\section{Kegiatan Bersih Pantai Kejawanan}

\section{a. Perencanaan dan Koordinasi}

Perencanaan kegiatan dilakukan mulai dilakukan hari kamis tanggal 27 September 2018 dengan berkoordinasi antara tim pengabdi dan jajaran pudir III selaku pembina taruna. Kegiatan yang akan dilaksanakan membutuhkan keterlibatan taruna berjumlah banyak sehingga para jajaran pudir memutuskan akan melibatkan calon taruna (catar) dengan jumlah 281 orang dengan dibantu oleh para taruna muda AKMI Suaka Bahari Cirebon.

Selain jumlah personil yang dibicarakan dalam koordinasi juga tentang kebutuhan yang perlu disiapkan seperti perlengkapan dan bahan yang akan dibawa saat pelaksanaannya. Hasil diskusi tentang kebutuhan perlengkapan seperti plastik dan mobil truk pembawa sampah perlu disiapkan saat pelaksanaannya. Untuk truk sampah, memerlukan peran PPI Kejawanan karena mereka memiliki truk sampah. Permohonan izin tempat kepada PPN Kejawanan dilakukan demi prosedur yang baik.

\section{b. Survey}

Survey lokasi dilakukan antara tanggal 1 sampai dengan 7 Nopember 2018 untuk meninjau lokasi yang akan dijadikan fokus kegiatan bersih-bersih pantai. Pelaksanaan survey dilakukan oleh tim pengabdian kepada masyarakat dan didampingi oleh para jajaran Pudir III. Hasil survey mendapatkan lokasi pantai Kejawanan Cirebon menjadi fokus lokasi kegiatan ditunjukkan gambar 1.

\section{c. Koordinasi dengan KPPN Kejawanan}

Koordinasi dilakukan dengan petugas KPPN Kejawanan mulai dari tanggal 2 sampai dengan 26 Oktober 2018 yaitu dengan penyampaian surat pemberitahuan dan pembicaraan teknis kegiatan. Koordinasi dikoordinir oleh Pa Diyono dan Anam Topani selaku Kasi TU Kantor Pelabuhanan Perikanan Nasional (KPPN) Kejawanan.

\section{d. Persiapan}

Persiapan kegiatan dilaksanakan pada tanggal 27 Oktober 2018 bersih pantai Kejawanan dimulai dari pukul 06.00 WIB di kampus AKMI Suaka Bahari Cirebon. Persiapan dipimpin langsung oleh Pembantu Direktur III Bapak Mayor Ery J Lesmana, ST beserta jajarannya dan Tim Pengbdian Masyarakat yang dibantu oleh Taruna muda (Tarmud). Kegiatan persiapan dilakukan untuk mengkondisikan keadaan peserta pada saat kegiatan dilaksanakan di pantai Kejawanan.

Sebelum pelaksanaan dimulai acara diawali dengan pembukaan yang dibuka oleh Pudir I Bapak 
Septo Hindianthoro, ANT III, S.Sos selaku Penasehat dari kegiatan bersih pantai Kejawanan ditunjukkan gambar 2.

\section{e. Pelaksanaan}

Pelaksanaan bersih pantai pada tanggal 27 Oktober 2018 dimulai dari pukul 09.00 WIB dimana peserta dibagi menjadi dua Tim. Tim pertama ditempatkan di lokasi sekitar pantai dan tim kedua di lokasi jalur masuk pantai. Tim pertama berjumlah 150 orang dan Tim Kedua berjumlah 150 orang. Masing-masing tim dibimbing oleh Dosen AKMI Suaka Bahari. Tim I dibimbing oleh Bapak Thamrin Ali, AMK dan para jajaran Pudir III yaitu Bapak Dedeng, Bapak Kaso, Bapak Syahroni, sedangkan tim II dibimbing Bapak Warkim, dan Bapak Diyono.

Tim pertama beserta masyarakat nelayan dan pedagang di sekitar pantai Kejawanan mengambil sampah yang berserakan di pantai. Pengambilan sampah dilakukan dengan cara menyebar secara teratur karena lokasinya yang cukup luas. Sampah-sampah yang sudah diambil kemudian dikumpulkan. Sedangkan tim kedua beserta masyarakat nelayan mulai mengambil sampah dari pintu gerbang masuk pantai Kejawanan hingga lokasi pantai. Dengan cara yang agak berbeda dengan tim satu, dimana tim kedua melakukan metode penyisiran sepanjang jalan. Sampah-sampah yang diambil kemudian dikumpulkan.

Pada akhir area pengambilan tim satu dan tim dua saling bertemu di pantai Kejawanan yang dilanjutkan ke area warung-warung bibir pantai. Sampah-sampah di sekitar warung agak sulit dijangkau karena tertutup papan dan bambu-bambu warung pedagang ditunjukkan gambar 3 .

\section{f. Pengumpulan sampah}

Sampah yang sudah diambil kemudian dikumpulkan dalam kantong sampah besar ukuran $120 \mathrm{x}$ $90 \mathrm{~cm}$. Kantong-kantong sampah besar yang sudah terisi kemudian dimasukkan ke dalam truk sampah. Truk sampah disedikan oleh pihak PPN Kejawanan berjumlah 1 truk ditujukkan pada gambar 4.

\section{g. Pembuangan Akhir Sampah}

Sampah yang sudah dikumpulkan di mobil truk sampah kemudian dibuang di tempat penampungan dan pembakaran sampah akhir yang sudah tersedia di pantai Kejawanan. Kami hanya mengantarkan ke tempat pembuangan akhir tanpa melakukan pembakaran sampah karena sudah diatur oleh pengelola pantai Kejawanan.

\section{h. Penutup}

Kegiatan penutup dilakukan pada pukul 12.00 WIB yang kemudian para peserta kembali ke kampus. Sementara para catar kembali ke asrama untuk makan siang yang sudah disiapkan di asramanya. 


\section{Pembinaan Terhadap Masyarakat Pantai Kejawanan}

Hasil dari kegiatan bersih pantai Kejawanan membentuk kelompok masyarakat sadar lingkungan pantai. Penumbuhan kesadaran dilakukan dengan pembinaan dengan metode wawancara dan himbauan oleh peserta pelaksana pengabdian kepada masyarakat. Proses pembinaan kepada masyarakat ini dibantu oleh petugas KPPN yang memiliki kewenangan terhadap pengelolaan pantai Kejawanan. Pelaksanaan pembinaan ditujukan bagi pedagang khususnya dan bagi masyarakat pengunjung/wisatawan pada umumnya.

\section{KESIMPULAN DAN SARAN}

Partisipasi masyarakat dalam penanganan sampah dapat meningkatkan kesadaran masyarakat akan pentingnya kebersihan lingkungan yang bersih dan sehat serta menguatkan inisiatif masyarakat dalam menjaga, memelihara dan meningkatkan fungsi ekosistem. Pantai Kejawanana Cirebon sebagai pantai penangkapan ikan dan tempat wisata menjadi wilayah yang berpengaruh terhadap peningkatan ekonomi masyarakat. Kesadaran masyarakat akan lingkungan yang bersih dan tertata dengan baik untuk masalah sampah perlu ditingkatkan karena terkadang masyarakat lupa. Maka, melalui aksi bersih sampah ini masyarakat diingatkan kembali akan kesedaran menjaga pantai Kejawanan yang bersih dan indah.

Berdasarkan hasil kegiatan ini, beberapa saran diantaranya:

1. Pembinaan terhadap kesadaran masyarakat akan membuang sampah di tempat sampah dilakukan secara kontinyu.

2. Tempat penampungan sampah di beberapa tempat sementera sebaiknya dikontrol oleh pengelola pantai kejawanan.

3. Pengelolaan sampah pada tempat pembuangan akhir sebaiknya dipisahkan antara sampah organik dan non organik.

\section{UCAPAN TERIMA KASIH}

Ucapan terima kasih penulis sampaikan kepada Direktur AKMI Suaka Bahari dan Kantor PPN Kejawanan Kabupaten Cirebon atas bantuan dana dan dukungan.

\section{DAFTAR PUSTAKA}

Anonim. 2007c. Undang-undang Nomor 27 tahun 2007, tentang Pengelolaan Wilayah Pesisir dan Pulaupulau Kecil.

Asyiawati. 2010. Analisis Status Ekosistem Pesisir bagi Penyusunan Rencana Tata Ruang Wilayah Pesisir di Kawasan Teluk Kota Ambon: Disertasi tidak diterbitkan. Bogor: Institut Pertanian Bogor 
Chua TE. 2006. The Dynamic of Integrated Coastal Management : Practical Applications in the Sustainable Coastal Development in East Asia. Global Environment Facility/UNDP/PEMSEA. Quezone City.

Dahuri R, Rais J, Sitepu MJ. 1996. Pengelolaan Sumberdaya Wilayah Pesisir dan Lautan Secara Terpadu. Jakarta : Pradnya Paramita.

Kay, R, and Alder. J. 1999. Coastal Management and Planning. New York : E \& FN SPON. 


\section{LAMPIRAN}

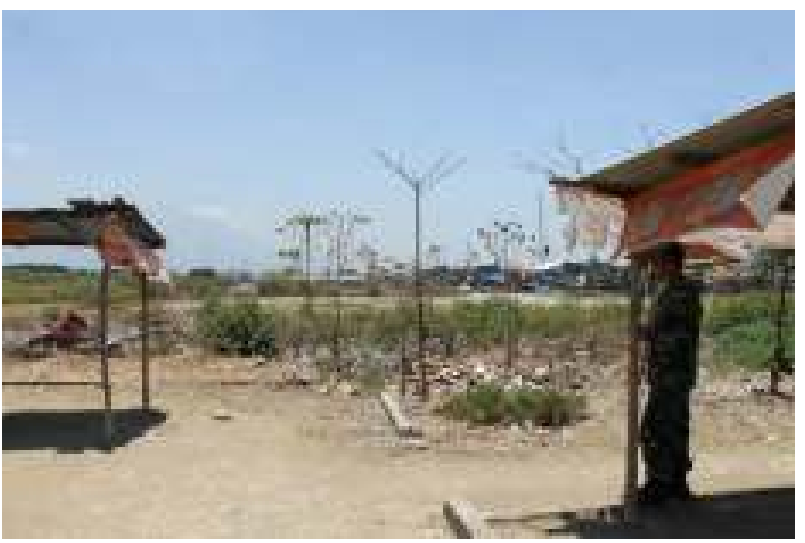

Gambar 1. Survery lokasi pantai Kejawanan Cirebon
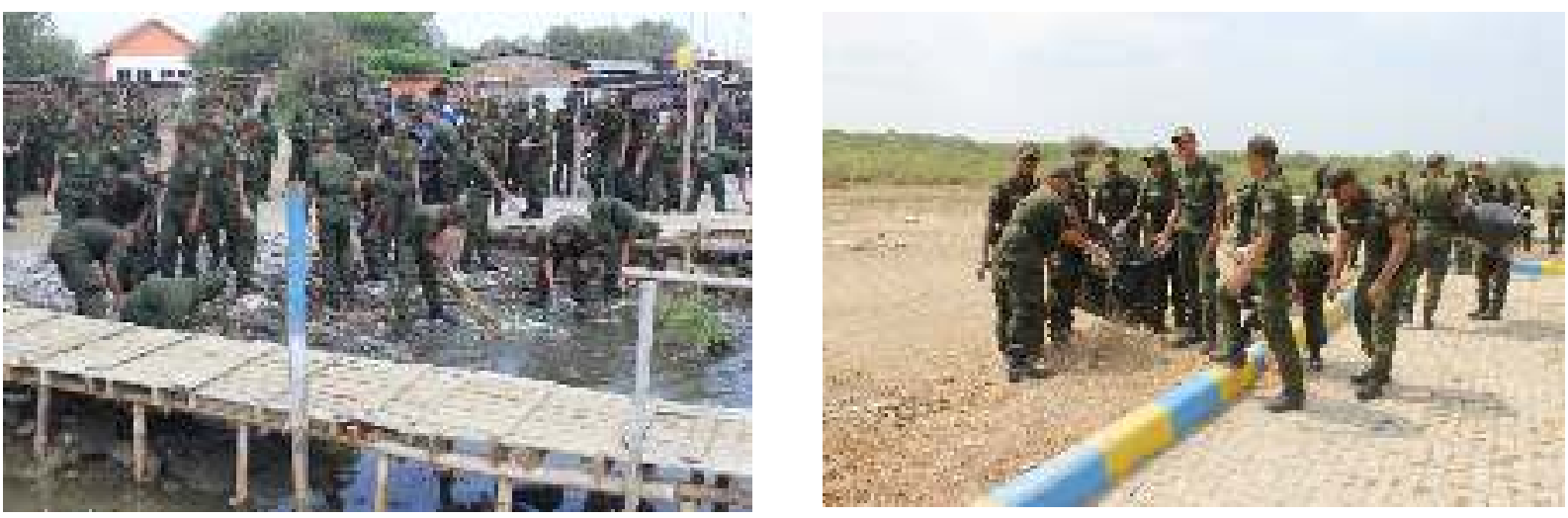

Gambar 3. Pengambilan sampah di lokasi
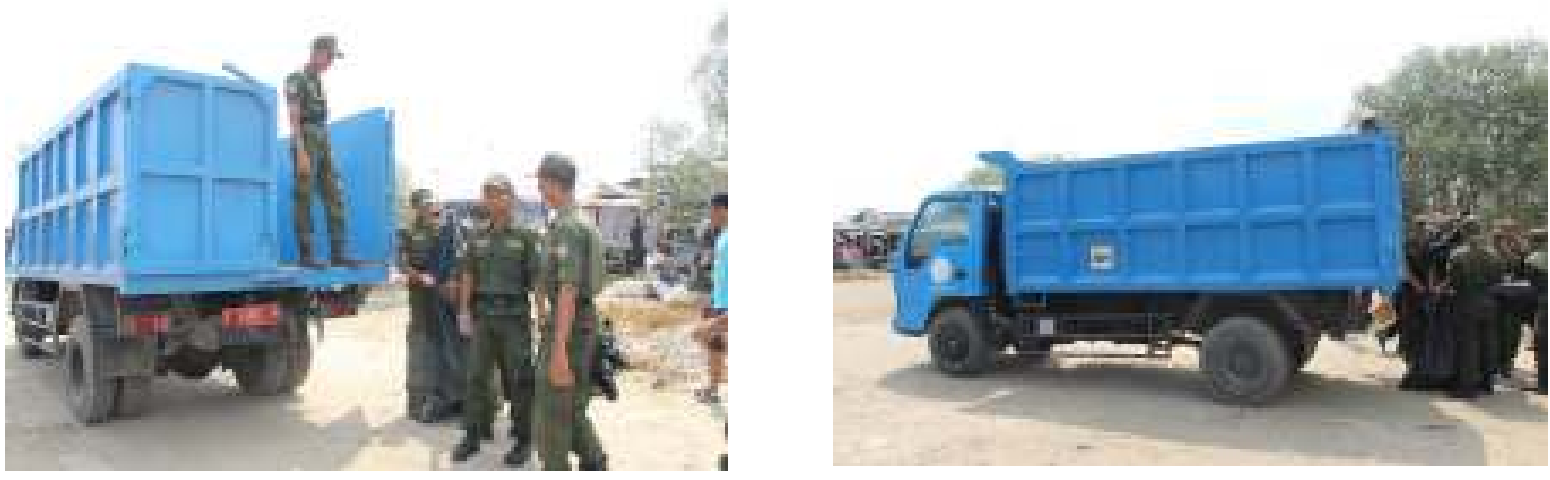

Gambar 4. Pengumpulan sampah dimasukkan kepada truk sampah 